\title{
Pathogenicity of streptococcus agalactiae in oreochromis niloticus
}

\author{
Yang He ${ }^{1,6, *}$, Jin-Lu Huang ${ }^{5, *}$, Kai-Yu Wang ${ }^{1,2}$, De-Fang Chen ${ }^{2}$, Yi Geng ${ }^{1}$, Xiao-Li \\ Huang ${ }^{2}$, Ping Ou-Yang ${ }^{1}$, Yi Zhou ${ }^{3}$, Jun Wang ${ }^{6}$, Jie Min ${ }^{4}$ and Wei-Min Lai ${ }^{1}$ \\ ${ }^{1}$ Department of Basic Veterinary, College of Veterinary Medicine, Key Laboratory of Animal Disease and Human Health of Sichuan \\ Province, Sichuan Agricultural University, Wenjiang, Sichuan, 611130, P. R. China \\ ${ }^{2}$ Department of Aquaculture, College of Animal Science and Technology, Sichuan Agricultural University, Wenjiang, Sichuan, \\ 611130, P. R. China \\ ${ }^{3}$ College of Life Science, Sichuan Agricultural University, Ya'an, Sichuan, 625000, P. R. China \\ ${ }^{4}$ College of Veterinary Medicine, Sichuan Agricultural University, Wenjiang, Sichuan, 611130, P. R. China \\ ${ }^{5}$ Veterinary Research Institution of Haida, Guangdong, Guangzhou, 511490, P.R. China \\ ${ }^{6}$ College of Life Science, Neijiang Normal University, Neijiang, Sichuan, 641100, P. R. China \\ *These authors contributed equally to this work
}

Correspondence to: Kai-Yu Wang, email: kywang1955@126.com

Keywords: oreochromis niloticus; group B streptococcus; histopathology; ultrapathology; ISH-PCR

Received: April 25, $2017 \quad$ Accepted: October 28, $2017 \quad$ Published: January 02, 2018

Copyright: $\mathrm{He}$ et al. This is an open-access article distributed under the terms of the Creative Commons Attribution License 3.0 (CC BY 3.0), which permits unrestricted use, distribution, and reproduction in any medium, provided the original author and source are credited.

\section{ABSTRACT}

To extend our understanding of the pathogenesis of group B streptococcus (GBS), an infection model was established in the Nile tilapia, and the $50 \%$ lethal dose (LD50), the toxicity of the extracellular products, the histopathology, ultrapathology, and dynamic distribution of the bacterium were evaluated. After experimental intraperitoneal (i.p.) infection of the Nile tilapia, the LD50 of GBS resuspended in normal saline was $2.3 \times 10^{7} \mathrm{cfu} / \mathrm{mL}$ and that of GBS resuspended in bacterial culture medium was $7.7 \times 10^{6} \mathrm{cfu} / \mathrm{mL}$. Enzymatic analysis of the extracellular products detected lipase and urease activities. The affected fish showed gross symptoms similar to those of naturally infected fish, including external signs (lethargy, abdominal distension, and abnormal swimming) and internal signs (hemorrhagic liver, enlarged and reddened spleen, hyperemic brain and kidney, empty stomach, and hemorrhagic enteritis). Histologically, hemorrhage, congestion, edema, and necrosis were apparent in the liver, kidney, spleen, heart, and brain. Bacterial colonization was first observed at $2 \mathrm{~h}$ postinfection (hpi) in the spleen, $4 \mathrm{hpi}$ in the liver, and $12 \mathrm{hpi}$ in the kidney, brain, and heart. Ultrastructurally, the cells showed nuclear shrinkage, hydropic mitochondrial damage, and increased secondary lysosomes. The bacteria were freely disseminated in the cytoplasm of phagocytes, brain microvascular endothelial cells, neurons, and blood vessels. These results indicate that GBS and their extracellular products are pathogenic to the Nile tilapia, damaging its splenic phagocytes, vascular and renal endothelial cells, liver hepatocytes, and brain neurocytes.

\section{INTRODUCTION}

The Nile tilapia (Oreochromis niloticus) is a relatively large cichlid fish, and one of the first fish species cultured worldwide. It is known as the "aquatic chicken" of the human diet, and it is particularly consumed by pregnant women and children [1]. Since the first trial in Kenya in 1920, the tilapia has been cultured in over 100 countries around the world, because its growth rate is high and it is highly tolerant of different culture conditions [2]. Streptococcus agalactiae (group B streptococcus, GBS) is a major Gram-positive coccus-shaped pathogen. Based on the Lancefield classification, it is the only serogroup B streptococcal species [3]. This coccus has become one of the most serious aquatic pathogens, with great ecological and economic impacts. It is a natural 
pathogen of the tilapia, causing infections around the world, with mortality rates of $30 \%-100 \%[4,5]$. The histopathology of GBS-infected tilapia has been described in order to assist its diagnosis [6-8]. Infected fish are characterized by septicemia and meningoencephalitis, with the main clinicopathological signs of lethargy, unilateral or bilateral exophthalmia, corneal opacity, and abdominal distension $[9,10]$.

Although several studies have documented the virulence factors of GBS, there is still limited information on the interactions between the pathogen and the Nile tilapia. To extend our understanding of the pathogenesis of GBS in the Nile tilapia, an infection model was established, and the median lethal dose $\left(\mathrm{LD}_{50}\right)$, the toxicity of the extracellular products, the histopathology, ultrapathology, and dynamic distribution of GBS were evaluated in this study.

\section{RESULTS}

\section{$\mathbf{L D}_{50}$ values}

To determine the pathogenicity of GBS, the $\mathrm{LD}_{50}$ was determined. GBS was isolated from the livers and spleens of all dead fish. The fish injected with GBS or GBS $+\mathrm{BC}$ displayed both early- and late-onset disease, and mortality occurred continuously throughout the experiment. After infection, the fish showed $0 \%-100 \%$ mortality in groups $\mathrm{A}$ and $\mathrm{B}$, with $\mathrm{LD}_{50}$ values on day 15 of $2.3 \times 10^{7} \mathrm{cfu} /$ fish and $7.7 \times 10^{6} \mathrm{cfu} /$ fish, respectively (Table 1). The clinical signs induced by GBS and GBS+BC were similar to those in naturally infected fish, including lethargy, opercular hemorrhage, erratic swimming, corneal opacity (Figure 1B), abdominal distension (Figure 1C), and opercular hemorrhage (Figure 1D), except that unilateral or bilateral exophthalmia was not present (Figure 1A). When these fish were dissected, hepatic hemorrhage (Figure 1E), splenomegaly (Figure $1 \mathrm{~F}$ ), thinned intestinal wall (Figure 1G), and meningitis (Figure 1H) were observed. The fish of the control group were active throughout the experiment, and showed neither mortality nor clinical signs.

\section{Lipase and urease activities in the ECPs}

To determine the virulence factors of BC, the ECPs were extracted and the protease, lecithinase, amylase, lipase and urease activities were determined in vitro. The results showed that the ECPs were positive for lipase (Figure 2A) and urease activities (Figure 2B), but negative for all other enzyme activities tested.

\section{Histopathological changes}

To observe the pathological changes induced by GBS, spleen, liver, kidney, stomach, intestine, and brain tissues were sampled and embedded for analysis. The histopathological changes in these tissues were as follows.
Liver

The histopathological changes in the liver mainly presented as structural disorder, congestion, and atrophy. Hepatocytes displayed swelling, vacuolar degeneration, and necrosis. In some infected fish, hepatocytes showed reduced numbers of cytoplasmic vacuoles, which were replaced by increased eosinophilic ovoid hyaline bodies (Figure 3B). Throughout infection, GBS was commonly observed in the central veins (Figure $3 \mathrm{Cc}$ ), along the hepatic sinusoids, and in the hepatic cytoplasm of the artificially infected fish (Figure 3D).

\section{Spleen}

Compared with the structure of the normal spleen (Figure 4Aa), the infected samples showed acute hemorrhagic splenitis; the splenic sinus displayed hyperemia and hemorrhage, lymphocytes were reduced, the normal structure of the ellipsoids was disrupted, the reticulate endothelial cells were denatured and damaged, and the number of melanomacrophage centers (MMCs) was increased, with high contents of hemosiderin. GBS was trapped within the walls of the ellipsoids, leading to the focal necrosis of the ellipsoids (Figure 4B), and were engulfed by the reticulate endothelial cells of the red pulp (Figure 4Cc). In some infected fish, the red blood cells of the red pulp disappeared, and GBS aggregated throughout the tissues (Figure 4Dd).

\section{Kidney}

The most obvious changes were the degeneration and necrosis of the renal cells. The renal hemopoietic tissue was considerably reduced. The glomerulus was enlarged, the capillary network displayed congestion, and Bowman's capsule became narrow, with caduceus necrotic debris. The epithelia of the renal tubules showed swelling, separated from the basement membrane, and fell off into the lumen (Figure 5Bb).

\section{Brain}

The meninges of the infected fish showed marked thickening, and the parenchyma was loose, with a spongy appearance. The brain microvessels were congested and the vascular spaces widened. The neuronal cells showed swelling and vacuolar degeneration, with small vacuoles in the cytoplasm (Figure 5Dd).

\section{Stomach}

The gastric mucosa of the infected fish was degenerated, damaged, and had fallen into the gastric cavity. The gastric gland of the submucosa was distinctly edematous, and the gastric gland cells were swollen and 
Table 1: The $\mathrm{LD}_{50}$ of GBS resuspended with $0.85 \%$ normal saline or bacterial culture

\begin{tabular}{ccccccc}
\hline \multicolumn{1}{c}{ Group } & $\begin{array}{c}\text { Bacterial concentration } \\
(\mathbf{c f u} / \mathbf{m L})\end{array}$ & Injection dose (mL) & Number of fish & $\begin{array}{c}\text { Number of } \\
\text { death }\end{array}$ & $\mathbf{L D}_{\mathbf{5 0}} \mathbf{c f u} / \mathbf{m L}$ \\
\hline Group A & No.1 & $5.8 \times 10^{9}$ & 0.2 & 10 & 10 & $2.3 \times 10^{7}$ \\
& No.2 & $5.8 \times 10^{8}$ & 0.2 & 10 & 9 & \\
& No.3 & $5.8 \times 10^{7}$ & 0.2 & 10 & 7 & \\
& No.4 & $5.8 \times 10^{6}$ & 0.2 & 10 & 3 & \\
& No.5 & $5.8 \times 10^{5}$ & 0.2 & 10 & 0 & \\
& No.6 & NS & 0.2 & 10 & 0 & $7.7 \times 10^{6}$ \\
& No.1 & $6.6 \times 10^{9}$ & 0.2 & 10 & 10 & \\
& No.2 & $6.6 \times 10^{8}$ & 0.2 & 10 & 9 & 7 \\
\\
No.3 & $6.6 \times 10^{7}$ & 0.2 & 10 & 2 & \\
& No.4 & $6.6 \times 10^{6}$ & 0.2 & 10 & 1 & \\
& No.5 & $6.6 \times 10^{5}$ & 0.2 & 10 & 0 & \\
\hline
\end{tabular}
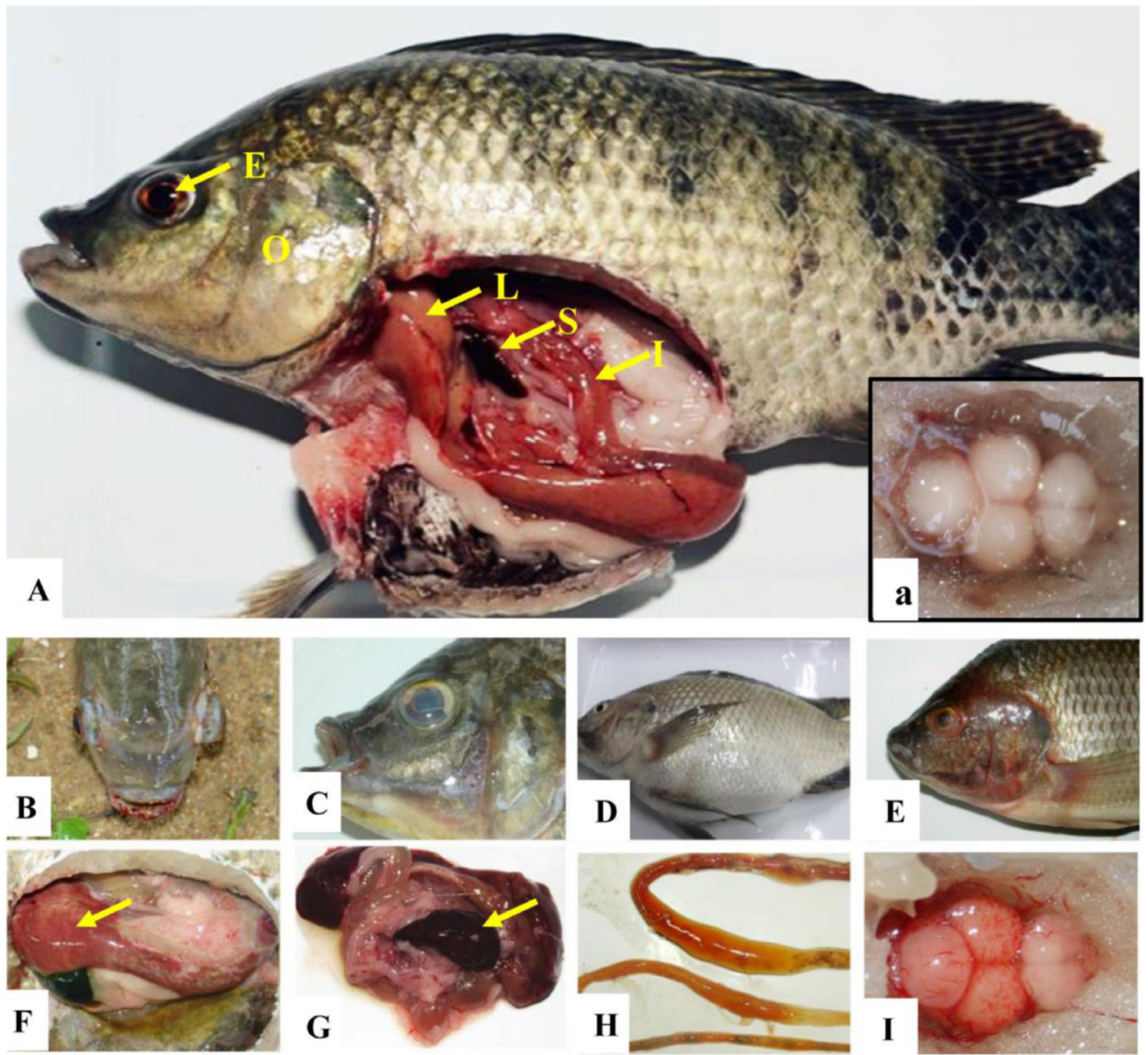

\section{C}

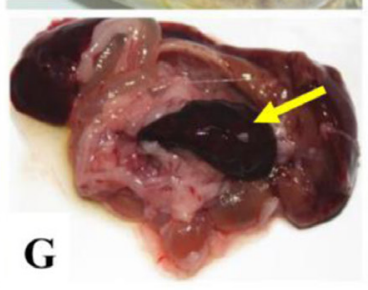

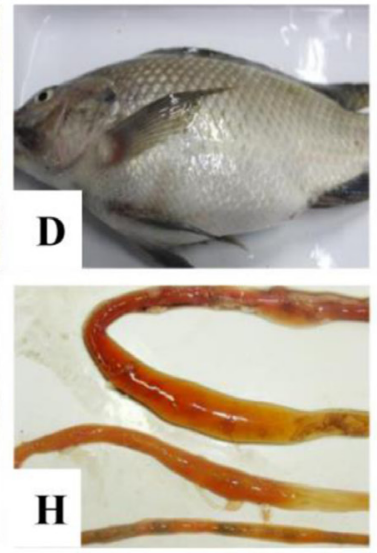
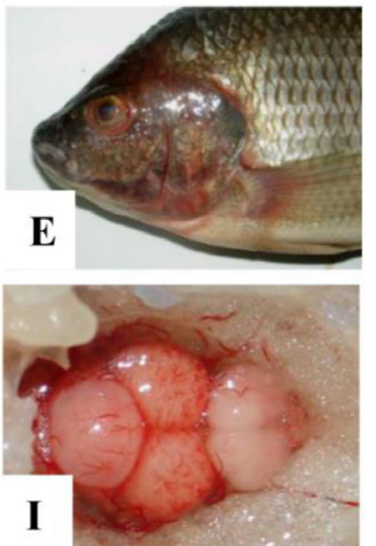

Figure 1: Clinical symptoms of nile tilapia infected by GBS. (A) Healthy tilapia, showing eye (E), opercular (O), liver (L), spleen (S), intestine (I) and brain (a). (B) Unilateral exophthalmia; (C) Corneal opacity; (D) Abdominal distension; (E) Opercular hemorrhage; (F) Hepatic hemorrhage (arrow); (G) Splenomegaly(arrow); (H) Thinned intestinal wall; (I) Meningeal congestion. 

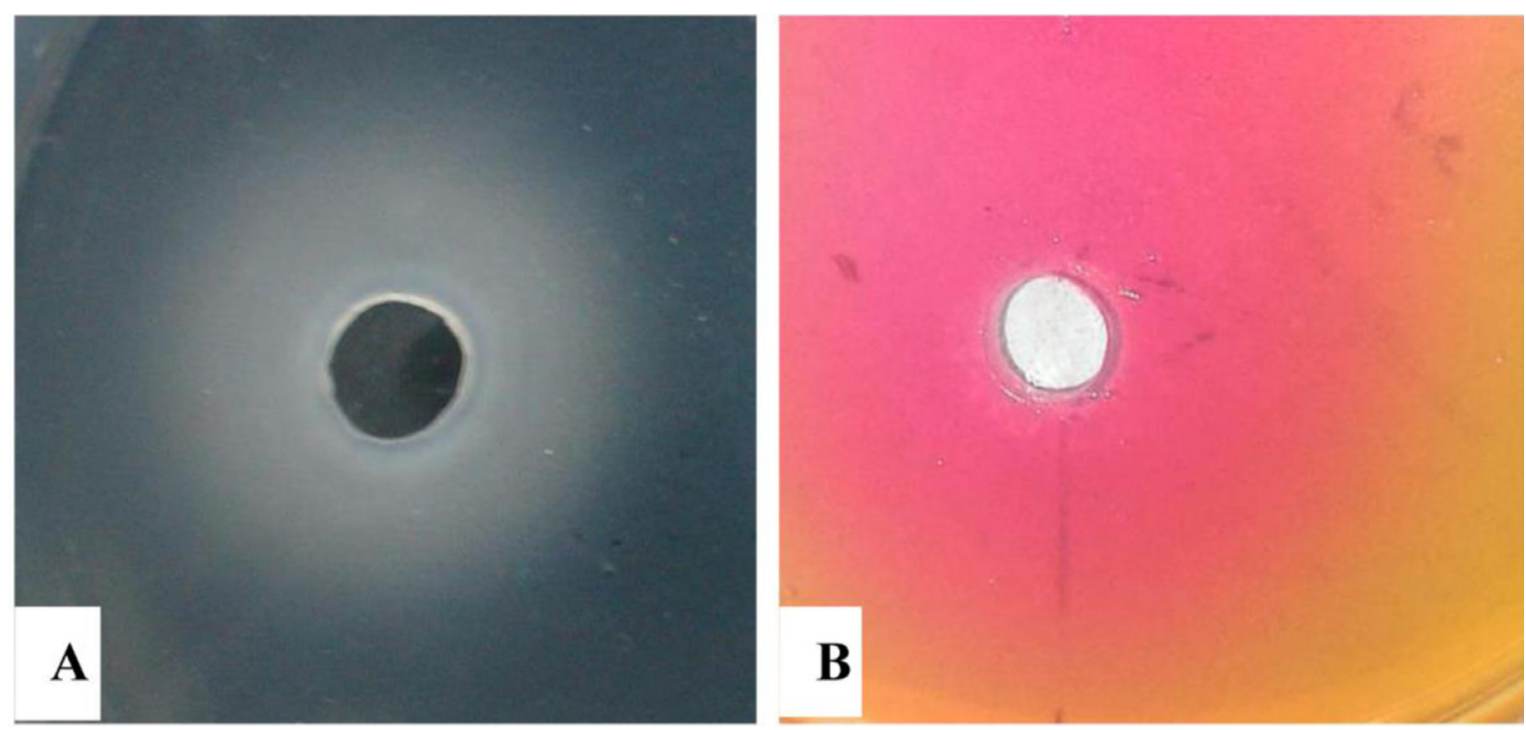

Figure 2: Enzymatic activities of ECPs produced by GBS. (A) The lipase activity, white halo around the ECPs; (B) The urease activity, pink halo around the ECPs.
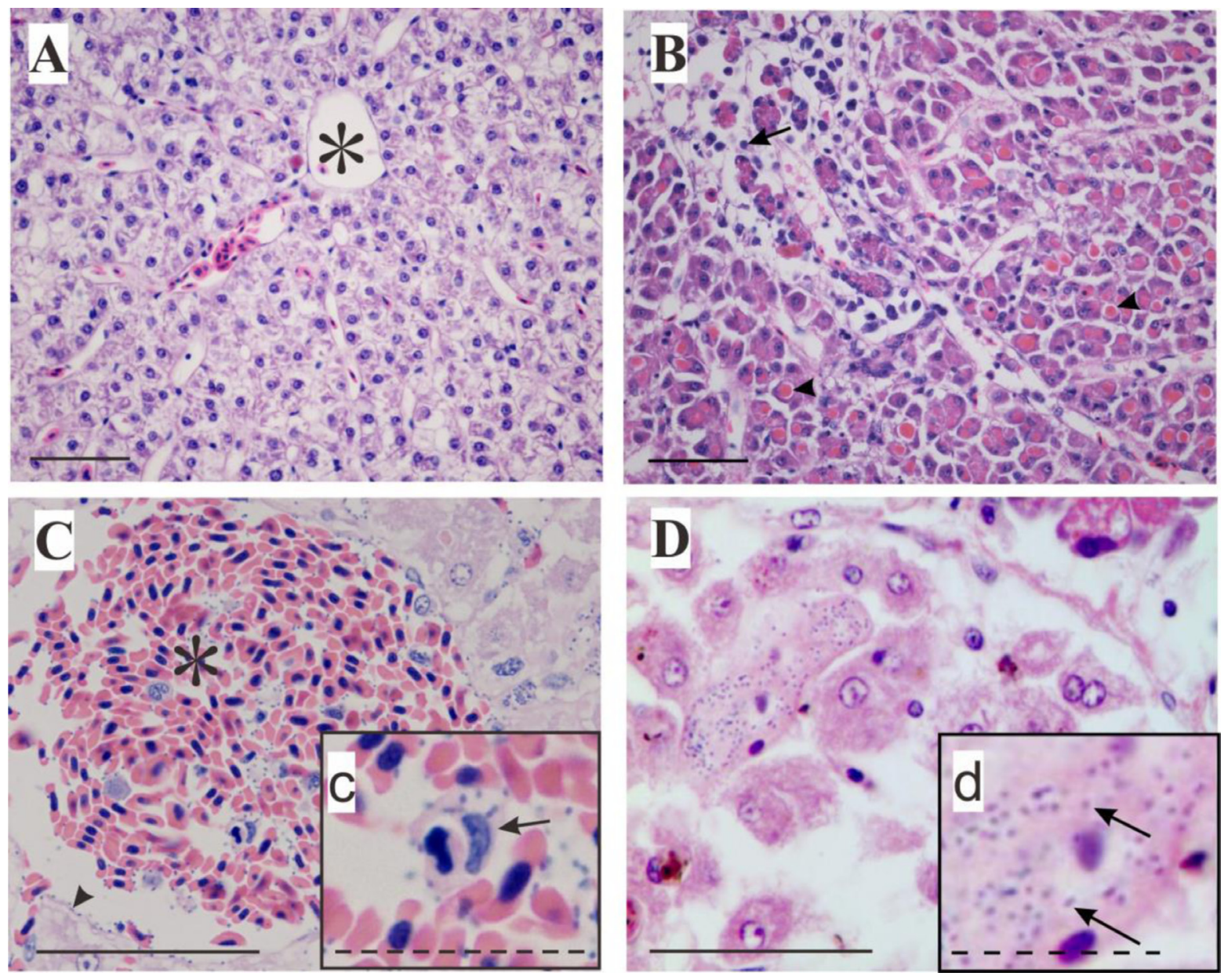

Figure 3: The histopathology of liver. Control (A) and GBS infected (B, Cc, Dd) H\&E. Solid line $=50 \mu \mathrm{m}$, dashed line $=25 \mu \mathrm{m}$. (A) Normal liver, * showing central vein; (B) Affected liver presented atrophic acinar cells (arrow) and degenerated hepatocytes with less vacuolar and more eosinophilic ovoid hyaline bodies (head arrow); (C) Congested central vein with bacteria attached by wall (head arrow), c. GBS attached to erythrocytes and engulfed by the monocytes (arrow); (D) Affected hepatocytes presented swelling and loss of lipid, d. GBS within hepatic cytoplasm (arrow). 
separated from the basement membrane (Figure 6B). The muscular layer showed necrosis, and the muscle fibers were ruptured, with vacuolar degeneration.

\section{Intestine}

The intestinal epithelial cells displayed necrosis and had fallen into the intestinal lumen. The goblet cells were disrupted and reduced in number. The major pathological change in the submucosa was edema (Figure 6D). The muscular layer showed the same changes as the stomach, including vacuolar degeneration and necrosis.

\section{Heart}

The normal heart is surrounded by a single layer of cells, with a distinct compact outer layer of muscle and an inner spongy layer, with numerous trabeculae (Figure 7Aa). In contrast, after infection, most of the fish had various degrees of pericarditis and myocarditis. The epicardium was thickened with edema and inflammatory cell infiltration. The myocardial cells showed eosinophilic staining, necrosis, and lysis, and the intercellular spaces had widened. Numerous blue- colored bacteria appeared in the pericardium or attached to myocardial cells (Figure 7Bb).

\section{Gill}

The gill lamellae of a healthy tilapia show the primary lamella (P) with arrays of delicate secondary lamellae (Figure 7C), which are surrounded by a single layer of respiratory epithelial cells. After infection, cell necrosis and shedding were the main symptoms of the secondary epithelium. Numbers of necrotic cells and inflammatory cells were observed between the gill lamellae. The capillaries of the gill lamellae displayed hyperemia, and some GBS were apparent in the pillar cells (Figure 7Dd).

\section{In situ hybridization (ISH)-PCR}

The main GBS-containing tissues (spleen, liver, kidney, heart, and brain) were sampled to investigate the dynamic distribution of GBS in the $36 \mathrm{~h}$ after infection (Table 2). ISH-PCR revealed GBS within the reticuloendothelial cells of the spleen at 2 hpi (Figure $8 \mathrm{~A})$, and in increased numbers at $36 \mathrm{hpi}$. GBS was first
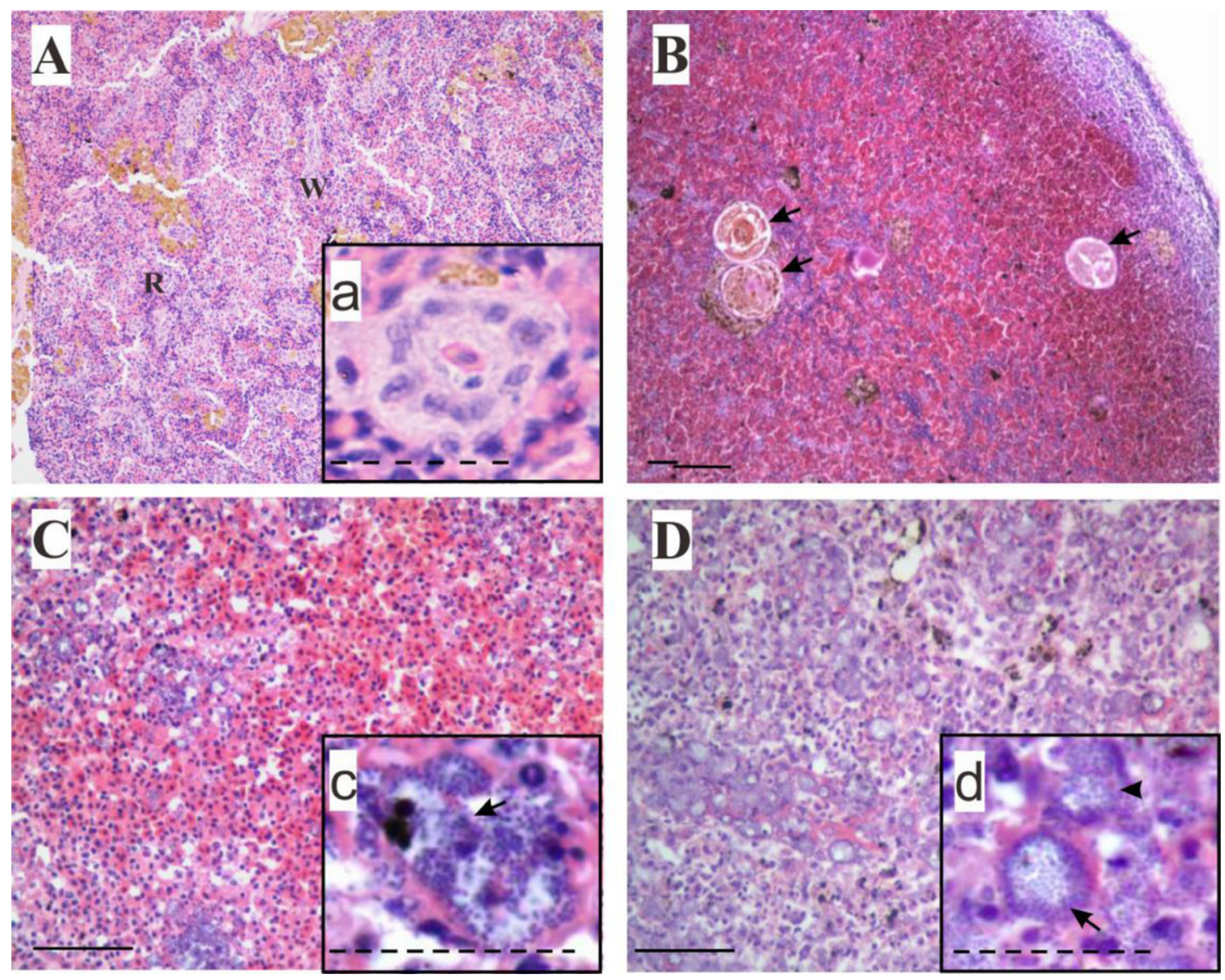

Figure 4: The histopathology of spleen in control (Aa) and GBS infected (B, Cc, Dd) nile tilapia. H\&E. Solid line $=50$ $\mu \mathrm{m}$, dashed line $=25 \mu \mathrm{m}$. (A) Normal spleen, showing red (R) and white (W) pulps, a. an ellipsoid; (B) Affected spleen presented severe congestion with focal necrosis (arrow); (C) Severe congested red pulps with focal bacterial aggregates, c. bacterial aggregates (arrow); (D) Affected spleen loaded with numerous bacteria, d. Ovoid bacteria-laden phagocytes (arrow), and disrupted phagocytes (head arrow). 
Table 2: Dynamic distribution of GBS detected using ISH-PCR

\begin{tabular}{lcccccc}
\hline \multicolumn{1}{c}{ Organ } & \multicolumn{6}{c}{ Detection time (h) } \\
\cline { 2 - 7 } & $\mathbf{2}$ & $\mathbf{4}$ & $\mathbf{6}$ & $\mathbf{1 2}$ & $\mathbf{2 4}$ & $\mathbf{3 6}$ \\
\hline Spleen & + & + & ++ & +++ & +++ & +++ \\
Liver & - & + & ++ & +++ & +++ & +++ \\
Kidney & - & - & - & + & + & + \\
Heart & - & - & - & - & + & + \\
Brain & - & - & - & + & + \\
\hline
\end{tabular}

detected in the hepatic sinusoids at 4 hpi (Figure 8B), and strong positive signals were observed in the hepatocytes and hepatic sinusoids at $36 \mathrm{hpi}$. The numbers of GBS detected in the kidney, heart, and brain were much lower than in the spleen and liver throughout the experimental period. The kidney and heart showed GBS at $12 \mathrm{hpi}$, mainly in the vessels of the glomerulus (Figure $8 \mathrm{C}$ ), the renal interstitium (Figure 8D), and the myocardial cells (Figure 8E). The brain was positive for GBS at $24 \mathrm{hpi}$, which were concentrated in the meninges (Figure 8F).

\section{Ultrapathology}

To observe GBS in the cells of tissues, the ultrapathological changes in the main GBS-containing organs (liver, spleen, kidney, and brain) were observed.
The ultrapathological changes in the infected tissues were as follows.

\section{Liver}

Increased secondary lysosomes were commonly observed in hepatocytes (Figure 9A). GBS were engulfed and digested by the lysosomes. The hepatocyte mitochondria became swollen and expanded into vacuoles (Figure 9B). The glycogen stores were depleted in most hepatocytes.

\section{Spleen}

Splenic lymphocytes were markedly decreased (Figure 9C). Free bacteria were observed within the
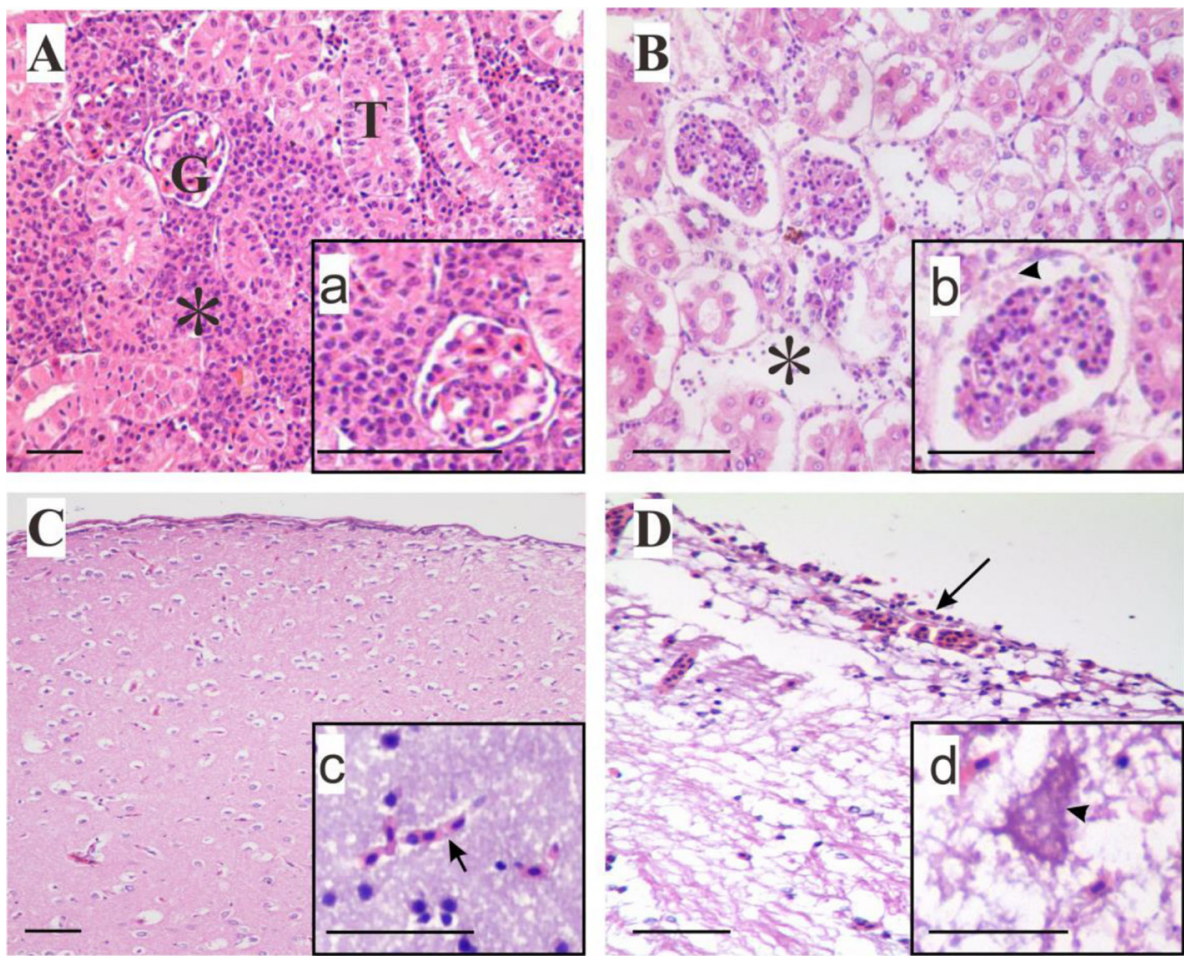

Figure 5: The histopathology of kidney and brain in control (Aa, Cc) and GBS infected (Bb, Dd) nile tilapia. H\&E. Solid line $=50 \mu \mathrm{m}$. (A) Normal renal corpuscles, showing glomerulus $(\mathrm{G})$, renal tubules $(\mathrm{T})$, and hemopoietic tissue $(*)$, a. A glomerulus; (B) Affected kidney showed severe tubulonephrosis and sharply decrease of hemopoietic tissue (*), b. Glomerulus congested and necrotic debris fell in the Bowman's capsule (head arrow); (C) Normal brain, showing thin meninges, c. brain microvessels(arrow); (D) Affected brain showed meningeal congestion (arrow), d. neuron exhibited vacuolar degeneration (head arrow). 
cytoplasm of the splenic macrophages and neutrophils (Figure 9D-9F). As the infection progressed, phagocytes showed necrosis and free bacteria were widely distributed.

\section{Kidney}

Epithelial cells in the renal tubules showed necrosis. The electron density of the nuclear chromatin decreased, and the mitochondria became swollen and vacuolated (Figure 9G).

\section{Brain}

The brain microvessels were broken. GBS were observed in the endothelial cells and microvessels, and the number of neurons clearly decreased (Figure 9H-9I). In their place, the numbers of microglia and inflammatory cells increased.

\section{DISCUSSION}

Group B streptococcus is a common fish pathogen, causing significant morbidity and mortality in at least 18 fish species, including tilapia, rainbow trout
(Oncorhynchus mykiss) [11], silvery pomfret (Pampus argenteus) [12], and ya-fish (Schizothorax prenanti) [13]. In the present study, the infected fish showed the same external signs as reported in previous studies, including lethargy, unilateral or bilateral exophthalmia, corneal opacity, and abdominal distension due to the extensive accumulation of ascites [4, 14]. Among these symptoms, exophthalmia is a typical clinical sign, displayed by almost all affected species. However, exophthalmia does not occur in all infected fish. A review of the reports of GBS infections suggested that the aquatic species, the bacterial serotype, and the infected environment are associated to some degree with exophthalmia. In Queensland, Australia, spontaneous infections in grouper caused unilateral or bilateral exophthalmia, and in another study, $71.8 \%$ of 300 red tilapia displayed exophthalmia [7]. However, in experimental infections, only $18 \%$ and $10 \%$ of Nile tilapia presented with exophthalmia [10]. This is consistent with the present study, insofar as most naturally infected fish had "pop-eye", whereas no fish with an experimental infection displayed exophthalmia.

$\mathrm{LD}_{50}$ is frequently used as a general indicator of the acute toxicity of a pathogen [15]. A previous study showed that the 7 day $\mathrm{LD}_{50}$ of $S$. agalactiae strain
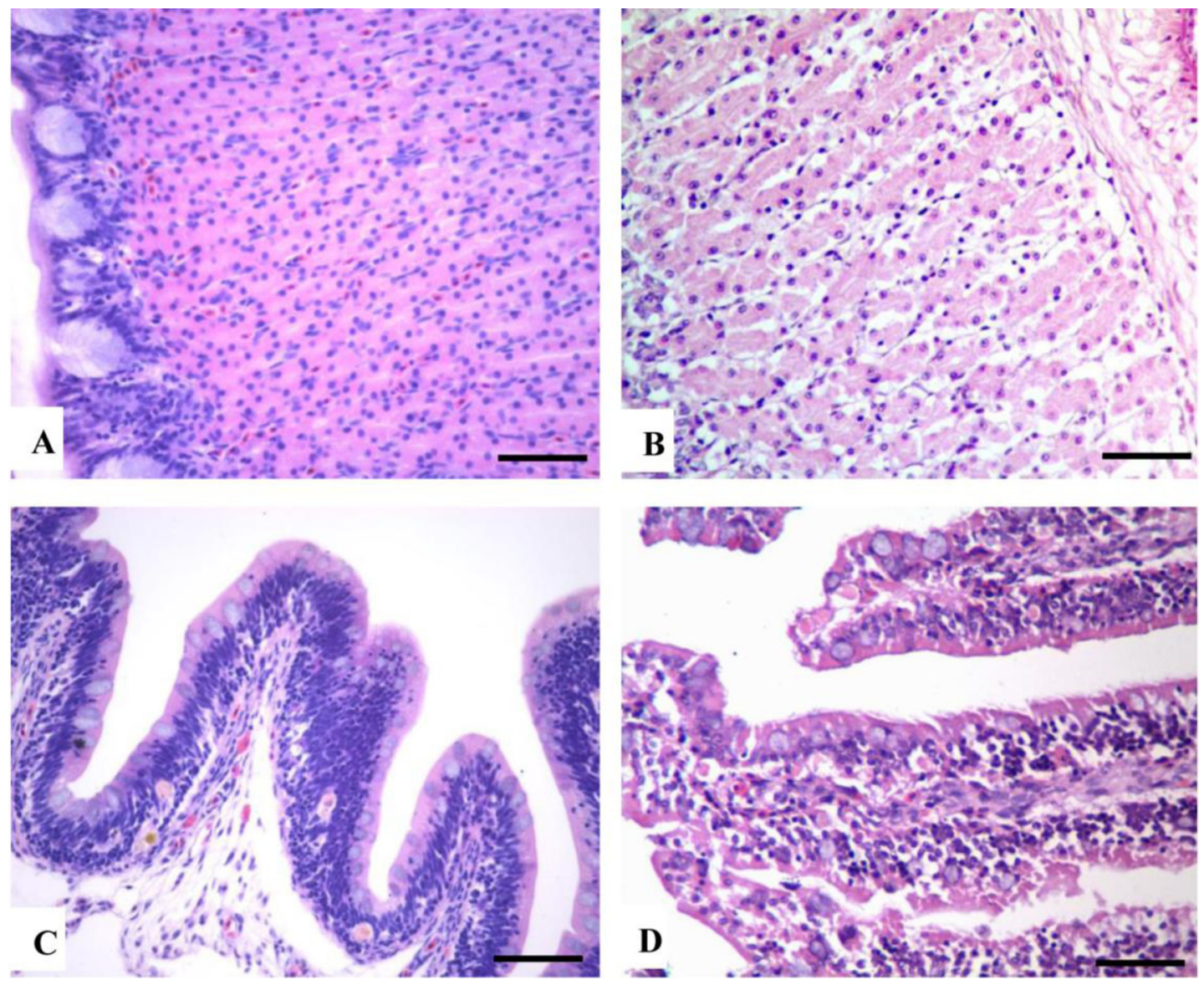

Figure 6: The histopathology of stomach and intestine in control (A, C) and GBS infected (B, D) nile tilapia. H\&E. Solid line $=50 \mu \mathrm{m}$, dashed line $=25 \mu \mathrm{m}$. (A) Normal stomach mucosa and gastric glands; (B) Affected gastric gland showed severe edema; (C) Normal intestine mucosa; (D) Affected intestine mucosa showed epithelia necrosis, and inflammatory cell aggregation. 
HN0101 resuspended in NS was $3.4 \times 10^{7} \mathrm{cfu} / \mathrm{mL}$ [16]. This is similar to the 15 day $\mathrm{LD}_{50}$ reported here $\left(2.3 \times 10^{7}\right.$ $\mathrm{cfu} / \mathrm{mL})$. Extracellular products are important virulence factors of fish pathogens. The $\mathrm{LD}_{50}$ of GBS+BC $\left(7.7 \times 10^{6}\right.$ $\mathrm{cfu} / \mathrm{mL}$ ) was lower than that of GBS+NS. Further analysis of the ECPs showed that they included lipase and urease activities. Lipase hydrolyzes lipid substrates and fulfills diverse functions in bacterial pathogenesis through host cell damage or modulation, inflammation, and cell signaling [17]. Straus [18] showed that the lipases of Pseudomonas cepacia inhibit bacterial phagocytosis by alveolar macrophages. Urease is known to enhance the survival of pathogens by hydrolyzing urea to supply them with nitrogen sources, increase the $\mathrm{pH}$ to favor their growth, and damage the surrounding epithelial cells [19]. Therefore, our results imply that the lipase and urease activities in BC contribute to the pathogenicity of GBS.

The spleen plays an important role in the destruction of aged red cells and captures hematogenous pathogens [20]. The high content of hemosiderin within melanomacrophages is a consequence of red cell destruction [21]. This is consistent with our observation that the spleens of infected fish showed fewer erythrocytes
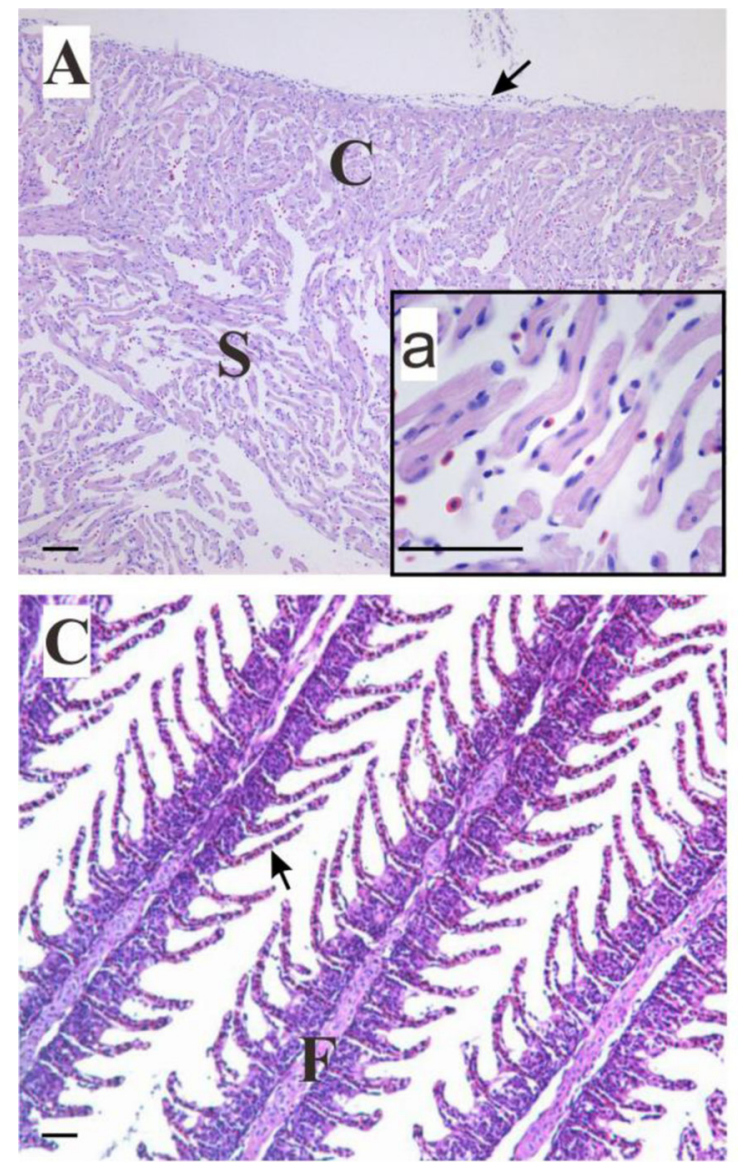

and more MMCs than the control spleens. The numbers of ellipsoids and macrophages were also reduced by the deficiency of oxygen and their destruction by virulence factors, and the blood-spleen barrier was impaired, leading to the spread of GBS to other organs (liver, heart, kidney, and brain). This is similar to the results of our previous study [22]. The liver breaks down lipids to meet the body's metabolic requirements, and the histology of hepatocytes showed the accumulation of large amounts of lipids in the cytoplasm [23]. A previous study showed that the liver becomes congested and edematous after infection [7]. In the present study, we also found lower fat vacuolation in the cytoplasm of hepatocytes, as observed in the liver after short-term mercury challenge [24]. After GBS infection, the Nile tilapia showed a loss of appetite, gastritis, and enteritis, leading to protein and energy break off. Therefore, the lipids in the hepatocytes might have been largely digested, after which the low-fat vacuolation of the hepatic cytoplasm became apparent. The histopathological changes in the brain and kidney were similar to those in previous reports, and indicated severe meningitis and renal tubule degeneration and necrosis [3, 25]. We have reported the histopathology of
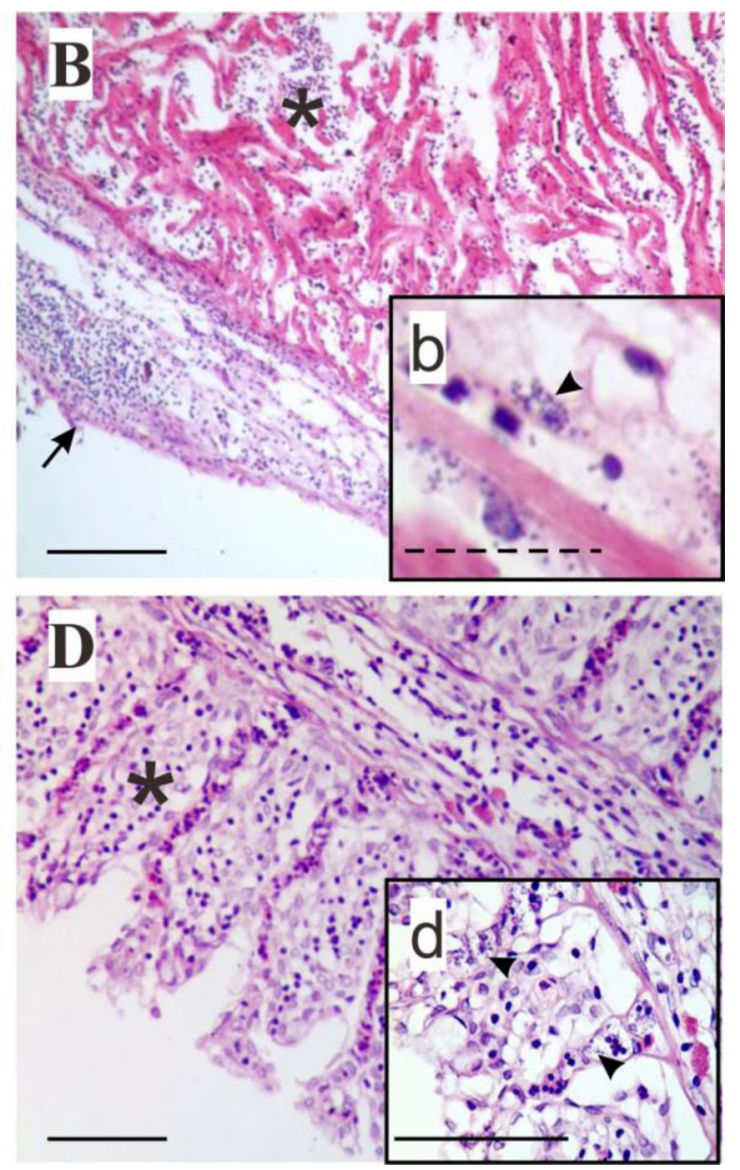

Figure 7: The histopathology of heart and gill in control (Aa, C) and GBS infected $(\mathbf{B b}, \mathrm{Dd})$ nile tilapia. H\&E. Solid line $=$ $50 \mu \mathrm{m}$, dashed line $=25 \mu \mathrm{m}$. (A) Normal heart structures, showing pericardium (arrow), compact layer (C) and spongy layer (S), a. Normal myocardium; (B) Affected heart presented severe pericarditis (arrow) and myocarditis (*), b. GBS attached to the myocardial cells (head arrow); (C) Normal gill, showing gill filament (F) and lamellae (arrow); (D) Affected gill presented lamellae necrosis (*) and covering respiratory epithelium slough off, $d$. Bacteria appeared in the pillar cells (head arrow). 
the fish heart after GBS infection for the first time, which showed serious pericarditis and myocarditis.

GBS can be localized with bacterial culture, PCR, quantitative PCR, ISH, IHC, and transmission electron microscopy (TEM). Among these, only ISH, IHC, and TEM can localize GBS in individual cells. The sensitivity of IHC varies with the type of antibody used [26]. ISHPCR allows the amplification of target sequences within intact cells and combines high sensitivity with the ability to localize specific DNA in tissues. It is more sensitive than ISH and produces less false positive results than PCR. cps $E$ encodes a well-conserved polysaccharide-producing protein present in the serotype-determining capsule of GBS [27]. Therefore, it was used as the target for GBS ISH-PCR. The immunohistochemical detection of GBS in red tilapia infected by the immersion route showed that the bacteria were present in the intestine and liver at $30 \mathrm{~min}$ post infection, then colonized the spleen and heart at $2 \mathrm{hpi}$,
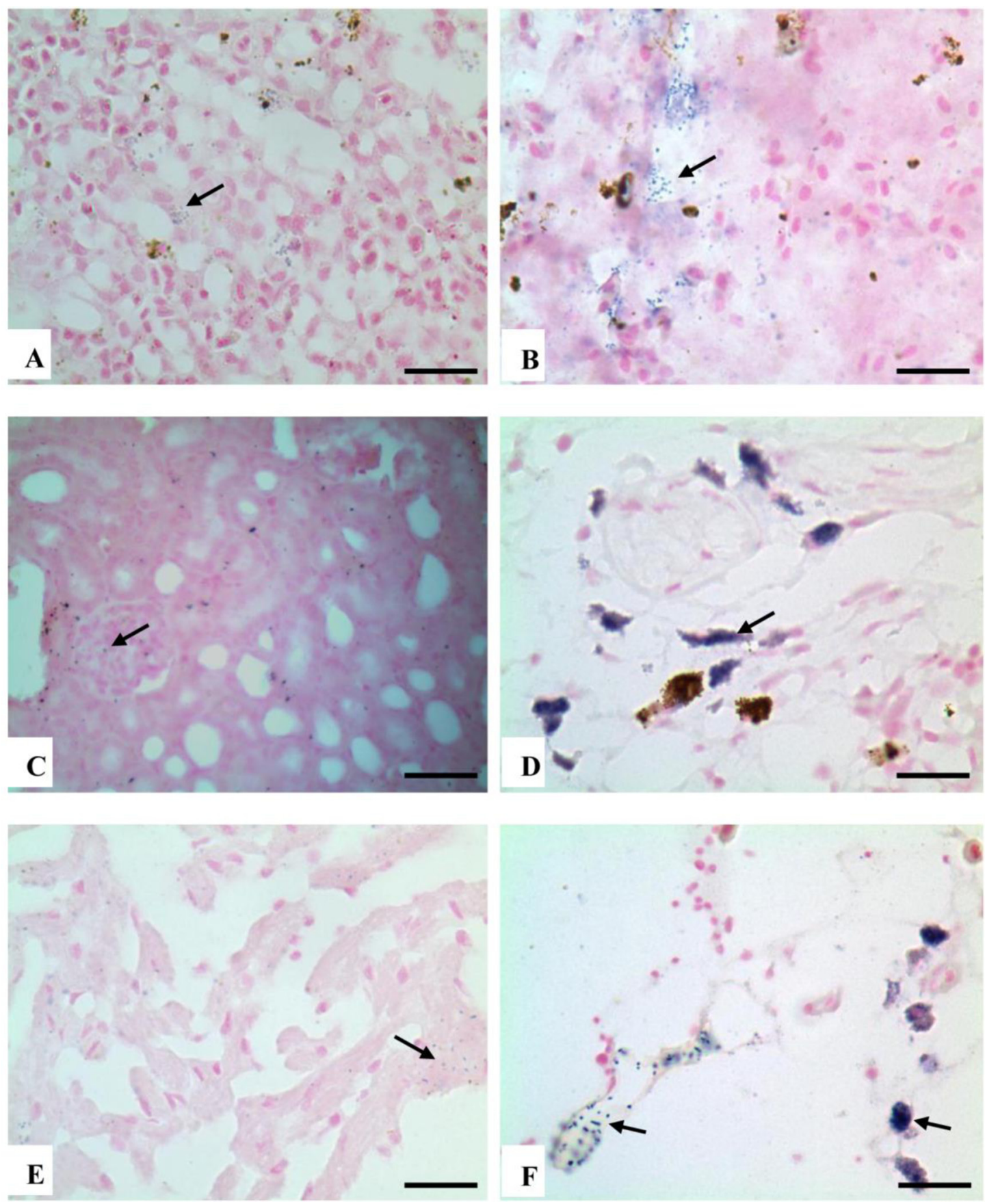

Figure 8: The detection of GBS by ISH-PCR. Solid line $=50 \mu \mathrm{m}$. (A) 2 hpi, GBS presented in the splenic reticuloendothelial cells (arrow); (B) 4 hpi, GBS presented in the hepatic sinusoids (arrow); (C) 12 hpi, GBS presented in the glomerulus (arrow); (D) 36 hpi, GBS presented in the phagocytes of renal interstitium (arrow); (E) 12 hpi, GBS presented in the myocardial cell (arrow); (F) 36 hpi, GBS presented in the capillary and phagocytes of meninges (arrow). 
and appeared in the kidney and brain at 4 hpi [28]. Our ISH-PCR results showed that after i.p. challenge, GBS were first detected in the spleen ( $2 \mathrm{hpi}$ ), followed by the liver (4 hpi), and then the kidney and brain (12 hpi). This discrepancy in the dynamic distribution of GBS might be attributable to the different infection routes used and the different virulence of the GBS. Notably, the spleen contained the largest number of GBS in both studies [28].

As an intracellular bacterium, GBS should be eliminated by a specific type of autophagy, known as "xenophagy" [29]. However, GBS can thwart the xenophagic pathway to invade endothelial cells and survive [30]. In the present study, free GBS was observed in macrophages, lymphocytes, hepatocytes, brain microvascular endothelial cells, and neurons, and induced the necrosis of macrophages and lymphocytes. These results suggest that GBS has evolved strategies to evade phagocytosis, and uses transcytosis to move to a suitable niche to avoid phagocytes. Bacterial debris was commonly observed in phagocytes and hepatocytes, indicating that phagocytosis by phagocytes and hepatocytes is involved in the immune clearance of GBS.

\section{MATERIALS AND METHODS}

\section{Bacteria}

Streptococcus agalactiae (HN0101) was obtained from diseased Nile tilapia [16] and stored at $-80^{\circ} \mathrm{C}$ until analysis. The bacterium was incubated in brain-heart infusion (BHI) broth (BD, USA) at $30^{\circ} \mathrm{C}$ for $24 \mathrm{~h}$ with shaking. The total bacterial DNA was prepared with the Genome DNA Extraction Kit (TianGen, China, approval no. 2011-028).
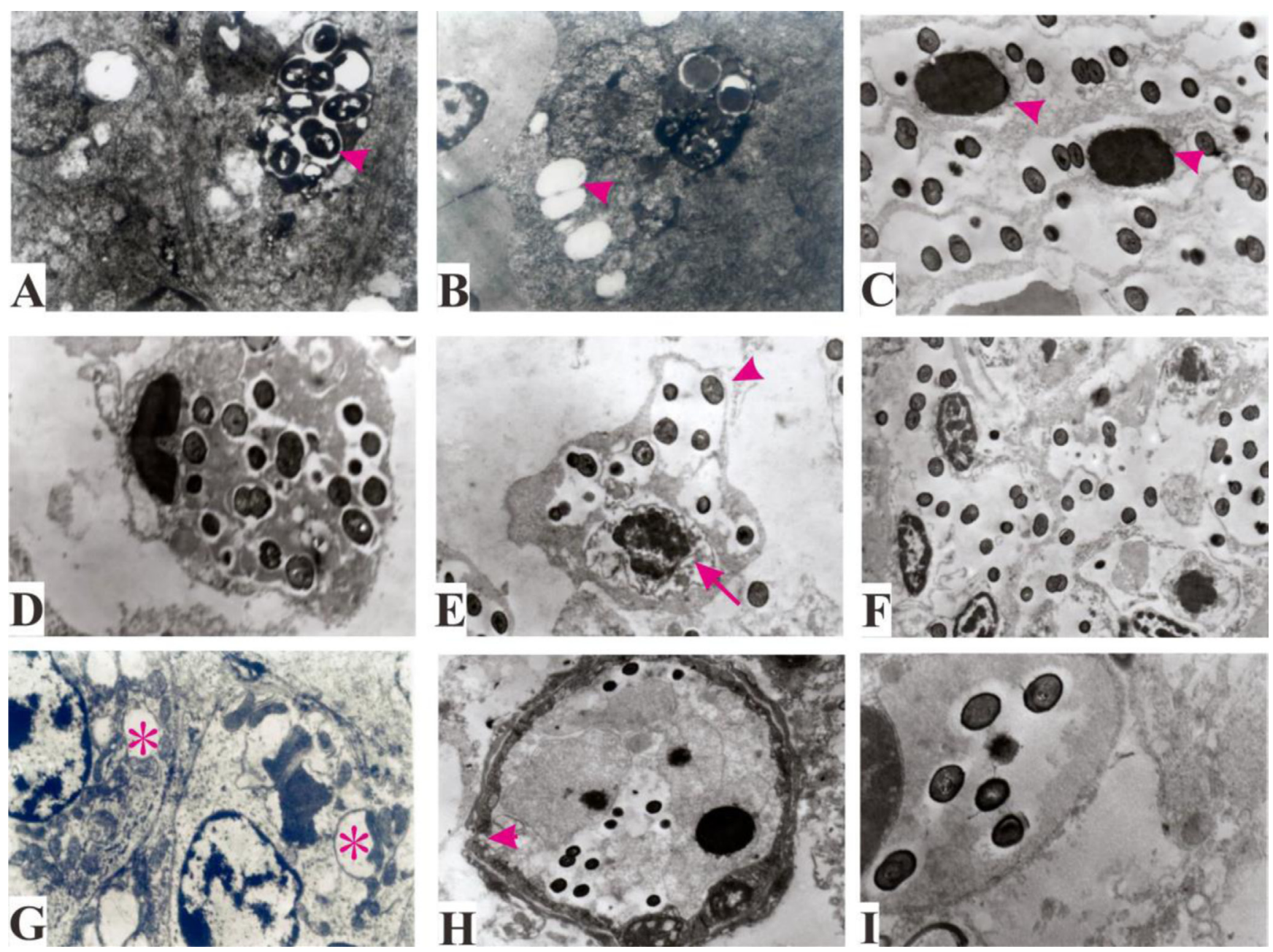

Figure 9: The ultrapathology of nile tilapia infected by GBS. (A) GBS dissected within the lysosome of hepatocytes (head arrow), TEM $\times 12000$; (B) Swollen hepatocytes with edged nucleus and vacuoles (head arrow), TEM $\times 10000$; (C) splenic lymphocytes showed nuclear pyknosis and surrounded by GBS (head arrow), TEM $\times 10000$; (D) Bacteria engulfed by splenic neutrophil, TEM $\times 10000$; (E) Splenic macrophage showed disrupted membrane (head arrow), enlarged nuclear membrane (arrow) and bacteria in the cytoplasm, TEM $\times 8000$; (F) Disseminated bacteria from the ruptured splenic macrophages, TEM $\times 7000$; (G) Vacuoles apperared in the renal tubule epithelia (*), TEM $\times 8000 ;(\mathbf{H})$ brain microvessel exhibited incomplete (head arrow), and bacteria freed in the lumen, TEM $\times 7000$; (I) GBS appeared in the brain microvessel epithelia cell, TEM $\times 12000$. 


\section{Nile tilapia}

Healthy Nile tilapia (mean weight $100 \pm 5 \mathrm{~g}$ ) with no history of GBS infection were purchased from a commercial tilapia farm and kept in $120 \mathrm{~L}$ aquaria at $30 \pm$ $1.0^{\circ} \mathrm{C}$ under a 12 -h light/dark cycle. The fish were fed a commercial diet at a feeding rate of $3 \%-5 \%$ body weight/ day. The animal studies presented in this manuscript were approved by the Animal Care Committee of Sichuan Agricultural University (Wenjiang, China, approval no. 2011-028).

\section{Determination of $\mathbf{L D}_{50}$}

The tilapia (120 fish) were divided equally into two challenges: group A was challenged with GBS + $0.85 \%$ normal saline (NS), and group B was injected with GBS resuspended in the BHI broth (BC) in which it was cultured for $24 \mathrm{~h}$ at $30^{\circ} \mathrm{C}$. The fish in each infection group were randomized into six groups (10 fish/group), five for GBS infection (nos. 1-5) and one as the negative control (no. 6). For GBS+NS infection, the bacteria were washed and suspended in NS to a concentration of $5.8 \times 10^{9} \mathrm{cfu} / \mathrm{mL}$, and were serially diluted 10 -fold to concentrations of $5.8 \times 10^{8}-5.8 \times 10^{5} \mathrm{cfu} / \mathrm{mL}$. The fish in group A (nos. 1-5) were injected intraperitoneally with $5.8 \times 10^{9}, 5.8 \times 10^{8}, 5.8 \times 10^{7}, 5.8 \times 10^{6}$, or $5.8 \times$ $10^{5} \mathrm{cfu} / \mathrm{mL}$ bacterial suspension, respectively, at $0.2 \mathrm{~mL} /$ fish. Group A no. 6 was injected with NS as the negative control. For GBS+BC infection, the bacteria were directly suspended in $\mathrm{BC}$ to a concentration of $6.6 \times 10^{9} \mathrm{cfu} / \mathrm{mL}$, and serially diluted 10 -fold with bacterial culture medium to concentrations of $6.6 \times 10^{8}-6.6 \times 10^{5} \mathrm{cfu} / \mathrm{mL}$. The fish of group B nos 1-5 were injected intraperitoneally with $6.6 \times 10^{9}, 6.6 \times 10^{8}, 6.6 \times 10^{7}, 6.6 \times 10^{6}$, or $6.6 \times 10^{5}$ $\mathrm{cfu} / \mathrm{mL}$ bacterial suspension, respectively, at $0.2 \mathrm{~mL} /$ fish. Group B no. 6 was injected with $\mathrm{BC}$ as the negative control.

Fish mortality was recorded for 15 days, and the $\mathrm{LD}_{50}$ values were calculated according to Koch's method [31]. The livers and spleens of all the dead fish were sampled for bacterial isolation and identification.

\section{Enzymatic activity of the extracellular products (ECPs)}

GBS was incubated in BHI broth at $30^{\circ} \mathrm{C}$ for $36 \mathrm{~h}$ with shaking. The bacterial cultures were then centrifuged at $12,000 \times \mathrm{g}$ for $30 \mathrm{~min}$ at $4^{\circ} \mathrm{C}$. The cell-free supernatants were sterilized with a $0.22 \mu \mathrm{m}$ microbiological filter and precipitated in $75 \%$ saturated ammonium sulfate for $24 \mathrm{~h}$ at $4^{\circ} \mathrm{C}$. The ECPs were collected by centrifugation at $12,000 \times \mathrm{g}$ for $30 \mathrm{~min}$, resuspended, and renatured by dialysis against $0.02 \mathrm{~mol} / \mathrm{L}$ Tris- $\mathrm{HCl}(\mathrm{pH} 7.5)$. The protein concentration in the crude ECPs was determined with the Bradford Protein Assay Kit (Takara, code no. T9310A) and standardized to $160 \mathrm{mg} / \mathrm{mL}$. The protease, lecithinase, amylase, lipase and urease activities were determined with the methods described by Yang [32].

\section{Histopathological analysis}

Samples of the liver, spleen, kidney, brain, stomach, intestine, heart, and gill of each moribund fish in group A were collected for pathological analysis. The tissues were fixed in $4 \%$ paraformaldehyde, processed routinely into paraffin wax sections, and stained with hematoxylin and eosin (HE).

\section{In situ PCR}

In situ PCR was performed with the method of Saltz [33], with minor modifications. Tilapia were infected i.p. with GBS $\left(2 \mathrm{LD}_{50}\right)$, and their spleen, liver, heart and brain tissues were sampled, fixed in $4 \%$ paraformaldehyde, and processed routinely into paraffin wax sections. The sections were cut to $3-5 \mu \mathrm{m}$ and rehydrated in an ethanol series and phosphate-buffered saline (PBS). The slides were incubated with $20 \%$ acetic acid for 15 $\mathrm{s}$ to inactivate any endogenous alkaline phosphatase. The sections were permeabilized by treatment with proteinase $\mathrm{K}$ at a final concentration of $0.1 \mu \mathrm{g} / \mathrm{mL}$ for $20 \mathrm{~min}$ at $37^{\circ} \mathrm{C}$. RNA was removed with DNase-free RNase $(10 \mu \mathrm{g} / \mathrm{mL})$ for $2 \mathrm{~h}$. Finally, the slides were rinsed with distilled deionized $\mathrm{H}_{2} \mathrm{O}\left(\mathrm{ddH}_{2} \mathrm{O}\right)$ and dehydrated in an ethanol series. The tissues were sealed with $25 \mu \mathrm{L}$ of PCR buffer: $2.5 \mu \mathrm{L}$ of $10 \times$ buffer, $4 \mu \mathrm{L}$ of $25 \mathrm{mM}$ $\mathrm{MgCl}_{2}, 1 \mu \mathrm{L}$ of $10 \mathrm{mM}$ dNTP, $1 \mu \mathrm{L}$ of $5 \mathrm{U} / \mu \mathrm{L}$ Taq DNA polymerase, $13.5 \mu \mathrm{L}$ of $\mathrm{ddH}_{2} \mathrm{O}$, and $1.5 \mu \mathrm{L}$ of each 10 $\mathrm{mM}$ cpsE primer, which are specific for GBS. The primer sequences were $5 \phi$-ATGAAAATTTGTCTGGTTGG-3 $\not \varnothing$ and $5 \phi$-TTAAAAAATTCCTCCTAAATT- $3 \phi$. The PCR thermal program consisted of denaturation at $94^{\circ} \mathrm{C}$ for $10 \mathrm{~min}$, followed by 30 cycles of $95^{\circ} \mathrm{C}$ for $1 \mathrm{~min}, 55^{\circ} \mathrm{C}$ for $1 \mathrm{~min}$, and $72^{\circ} \mathrm{C}$ for $1 \mathrm{~min}$, and concluded with $72^{\circ} \mathrm{C}$ for 10 min. Finally, the samples were fixed with $4 \%$ paraformaldehyde for $10 \mathrm{~min}$.

\section{In situ hybridization}

Hybridization was performed according to the instructions of the assay kit purchased from Boster of China (cat. no. Mk1032). The samples were prehybridized with prehybridization solution at $42^{\circ} \mathrm{C}$ for $3-4 \mathrm{~h}$. The GBS-specific probe, cpse (5ф-GAATGGTACTGCTACAGCGGC-3 $\not$ ) labeled with digoxigenin (DIG; $500 \mathrm{ng} / \mathrm{mL}$ in hybridization solution) was spotted onto the samples and denatured at $95^{\circ} \mathrm{C}$ for $10 \mathrm{~min}$. After incubation at $42^{\circ} \mathrm{C}$ for $12 \mathrm{~h}$, the unreacted probe was removed from the slides by washing. Blocking buffer was incubated with the samples at $37^{\circ} \mathrm{C}$ for $30 \mathrm{~min}$, and then replaced by alkaline-phosphatase-conjugated anti-DIG antibody and incubated at $37^{\circ} \mathrm{C}$ for $120 \mathrm{~min}$. After the samples were washed three times, they were 
incubated in $\mathrm{BCIP} / \mathrm{NBT}$ at $37^{\circ} \mathrm{C}$ for $20-30 \mathrm{~min}$ and restained with Nuclear Fast Red. Finally, the stained sections were dehydrated in ethanol, cleared in xylene, covered with cover glasses, and examined with a light microscope (Nikon, Tokyo, Japan). GBS was scored with the following criteria: $(-)$, no GBS, $(+)$ a few scattered GBS; $(++)$, medium amount of aggregated GBS; $(+++)$, massive levels of GBS, with $>80 \%$ of the tissue area positively labeled.

\section{Transmission electronic microscope examination}

The spleens, livers, kidneys, and brains from the moribund fish of group A were fixed in 2.5\% cold glutaraldehyde in $0.1 \mathrm{M}$ PBS ( $\mathrm{pH} 7.2$ ) for $24 \mathrm{~h}$. After The samples were washed twice and post fixed in $1 \%$ osmium tetraoxide in 0.1 M PBS ( $\mathrm{pH} 7.2$ ). The postfixed samples were dehydrated in a graded series of acetone $(30 \%$, $50 \%, 70 \%, 80 \%, 90 \%$, and $100 \%$ ), then infiltrated with 1:4 acetone:epon resin for $8 \mathrm{~h}$. After infiltration in pure epon resin for a further $2 \mathrm{~h}$, the samples were embedded in resin. Ultrathin sections were double-stained with uranium acetate and lead citrate, and examined with a transmission electron microscope [34].

\section{ACKNOWLEDGMENTS AND FUNDING}

We thank Mrs. Xiao-jiao Li for her assistance in the preparation of the all the materials. The authors declared no potential conflicts of interest with respect to the research, authorship, and publication of this article. This work was supported by the Sichuan Agricultural University (No. IRT0848).

\section{CONFLICTS OF INTEREST}

None.

\section{REFERENCES}

1. Brown CL, Yang TB, Fitzsimmons K, Bolivar RB. The value of pig manure as a source of nutrients for semiintensive culture of Nile tilapia in ponds (a review). Agricultural Sciences. 2014; 5:1182-93. https://doi. org/10.4236/as.2014.512128.

2. El-Sayed AFM. Tilapia culture. CABI Publishing. 2006.

3. Evans JJ, Klesius PH, Gilbert PM, Shoemaker CA, Sarawi MAA, Landsberg J, Duremdez R, Marzouk AA, Zenki SA. Characterization of $\beta$-haemolytic Group B Streptococcus agalactiae in cultured seabream, Sparus auratus L., and wild mullet, Liza klunzingeri (Day), in Kuwait. Journal of Fish Diseases. 2010; 25:505-13. https://doi.org/10.1046/j.13652761.2002.00392.x.

4. Naraid S, Kong F, Danny K, Gwendolynl G, Kidchakan S. Occurrence of rare genotypes of Streptococcus agalactiae in cultured red tilapia Oreochromis sp. and Nile tilapia O. niloticus in Thailand--Relationship to human isolates? Aquaculture. 2008; 284:35-40. https://doi.org/10.1016/j. aquaculture.2008.07.034.

5. Abdullah S, Omar N, Yusoff SM, Obukwho EB, Nwunuji TP, Hanan L, Samad J. Clinicopathological features and immunohistochemical detection of antigens in acute experimental Streptococcus agalactiae infection in red tilapia (Oreochromis spp.). Springerplus. 2013; 2:286-292. https://doi.org/10.1186/2193-1801-2-286.

6. Alsaid M, Daud HHM, Mustapha NM, Bejo SK, Abdelhadi YM, Abuseliana AF, Hamdan RH. Pathologicl Findings of Experimental Streptococcus Agalactiae Infection in Red Hyprid Tilapia (Oreochromis sp.). International Conference on Chemica. 2013:70-73. https://doi.org/10.15242/IICBE. C1213075.

7. Zamrisaad M, Amal MN, Sitizahrah A. Pathological changes in red tilapias (Oreochromis spp.) naturally infected by Streptococcus agalactiae. Journal of Comparative Pathology. 2010; 143:227-229. https://doi.org/10.1016/j. jcpa.2010.01.020.

8. Chang PH, Plumb JA. Histopathology of experimental Streptococcus sp. infection in tilapia, Oroochromis niloticus (L.), and channel catfish, Ictafurus punctatus (Ratinesque). Journal of Fish Diseases. 2010; 19:235-241. https://doi. org/10.1111/j.1365-2761.1996.tb00130.x.

9. Filho CI, Müller EE, Pretto-Giordano LG. Histological findings of experimental Streptococcus agalactiae infecion in nile tilapias (Oreochromis niloticus). Brazilian Journal of Veterinary Pathology. 2009; 2:12-5. http://bjvp.org.br.

10. Suwannasang A, Dangwetngam $M$, Issaro A, Phromkunthong W, Suanyuk N. Pathological manifestations and immune responses of serotypes Ia and III Streptococcus agalactiae infections in Nile tilapia (Oreochromis niloticus). Songklanakarin Journal of Science \& Technology. 2014; 36:499-506.

11. Amal MNA, Zamrisaad M. Streptococcosis in tilapia (Oreochromis niloticus): a review. Pertanika Journal of Tropical Agricultural Science. 2011; 34:195-206.

12. Duremdez R, Al-Marzouk A, Qasem JA, Al-Harbi A, Gharabally H. Isolation of Streptococcus agalactiae from cultured silver pomfret, Pampus argenteus (Euphrasen), in Kuwait. Journal of Fish Diseases. 2004; 27:307-310.

13. Geng Y, Wang KY, Huang XL, Chen DF, Li CW, Ren SY, Liao YT, Zhou ZY, Liu QF, Du ZJ. Streptococcus agalactiae, an emerging pathogen for cultured ya-fish, Schizothorax prenanti, in China. Transboundary \& Emerging Diseases. 2012; 59:369-75. https://doi.org/10.1111/j.18651682.2011.01280.x.

14. Bowater RO, Forbes-Faulkner J, Anderson IG, Condon K, Robinson B, Kong F, Gilbert GL, Reynolds A, Hyland S, Mcpherson G. Natural outbreak of Streptococcus agalactiae (GBS) infection in wild giant Queensland grouper, Epinephelus lanceolatus (Bloch), and other wild 
fish in northern Queensland, Australia. Journal of Fish Diseases. 2012; 35:173-86. https://doi.org/10.1111/j.13652761.2011.01332.x.

15. Miller FP, Vandome AF, Mcbrewster J. Median Lethal Dose. Alphascript Publishing. 2010.

16. Wang KY, Chen DF, Huang LY, Lian H, Wang J, Xiao D, Geng Y, Yang ZX, Lai WM. Isolation and characterization of Streptococcus agalactiae from Nile Tilapia Oreochromis niloticus in China. African Journal of Microbiology Research. 2013; 7:317-23. https://doi.org/10.5897/ AJMR12.1207.

17. Bender J, Flieger A. Lipases as Pathogenicity Factors of Bacterial Pathogens of Humans: Springer Berlin Heidelberg. 2010.

18. Straus DC, Lonon MK, Hutson JC. Inhibition of rat alveolar macrophage phagocytic function by a Pseudomonas cepacia lipase. Journal of Medical Microbiology. 1992; 37:335-40. https://doi.org/10.1099/00222615-37-5-335.

19. Collins CM, D'Orazio SE. Bacterial ureases: structure, regulation of expression and role in pathogenesis. Molecular Microbiology. 1993; 9:907-13. https://doi. org/10.1111/j.1365-2958.1993.tb01220.x.

20. Mebius RE, Kraal G. Structure and function of the spleen. Nat Rev Immunol. 2005; 5:606-16. https://doi.org/10.1038/ nri1669.

21. Fänge R, Nilsson S. The fish spleen: structure and function. Experientia. 1985; 41:152-8. https://doi.org/10.1007/ BF02002607.

22. He Y, Wang KY, Xiao D, Chen DF, Huang L, Liu T, Wang J, Geng Y, Wang EL, Yang Q. A recombinant truncated surface immunogenic protein (tSip) plus adjuvant FIA confers active protection against Group B streptococcus infection in tilapia. Vaccine. 2014; 32:7025-32. https://doi. org/10.1016/j.vaccine.2014.08.017.

23. Bruslé J, Anadon GG. The structure and function of fish liver. 1996: 77-93.

24. Kaewamatawong T, Rattanapinyopituk K, Ponpornpisit A, Pirarat N, Ruangwises S, Rungsipipat A. Shortterm exposure of Nile Tilapia (Oreochromis niloticus) to mercury: histopathological changes, mercury bioaccumulation, and protective role of metallothioneins in different exposure routes. Toxicologic Pathology. 2013; 41:470-479. https://doi.org/10.1177/0192623312457269.

25. Suanyuk N, Kanghear H, Khongpradit T, Supamattaya K. Streptococcus agalactiae infection in tilapia (Oreochromis niloticus). Songklanakarin Journal of Science \& Technology. 2005; 27:209-19.
26. Laiho JE, Oikarinen M, Richardson SJ, Frisk G, Nyalwidhe J, Burch TC, Morris MA, Oikarinen S, Pugliese A, Dotta F. Relative sensitivity of immunohistochemistry, multiple reaction monitoring mass spectrometry, in situ hybridization and PCR to detect Coxsackievirus B1 in A549 cells. Journal of Clinical Virology. 2016; 77:21-8. https://doi. org/10.1016/j.jcv.2016.01.015.

27. Yamamoto S, Miyake K, Koike Y, Watanabe M, Machida Y, Ohta M, Iijima S. Molecular characterization of typespecific capsular polysaccharide biosynthesis genes of Streptococcus agalactiae type Ia. Journal of Bacteriology. 1999; 181:5176-5184.

28. Iregui CA, Comas J, Vásquez GM, Verján N. Experimental early pathogenesis of Streptococcus agalactiae infection in red tilapia Oreochromis spp. Journal of Fish Diseases. 2015; 39:205-15. https://doi.org/10.1111/jfd.12347.

29. Jo EK, Yuk JM, Shin DM, Sasakawa C. Roles of autophagy in elimination of intracellular bacterial pathogens. Frontiers in Immunology. 2013; 4:1-9. https://doi.org/10.3389/ fimmu.2013.00097.

30. Cutting AS, Del RY, Mu R, Rodriguez A, Till A, Subramani S, Gottlieb RA, Doran KS. The Role of Autophagy during Group B Streptococcus Infection of Blood-Brain Barrier Endothelium. Journal of Biological Chemistry. 2014; 289:35711-23. https://doi.org/10.1074/jbc.M114.588657.

31. Cui-Ping LI, Min-Yao WU, Wang HY. LC_(50) Caculated by Kochi,Probit Analysis and Linear Regression Methods. Progress in Veterinary Medicine. 2012.

32. Yang HE. Investigation on the pathogenicity of extracellular products of a high virulence strain isolated from Ictalurus punctatus. Journal of Fisheries of China. 2015; 40:457-67. https://doi.org/10.11964/jfc.20150910060.

33. Saltz J, Petition S, Berryman H, Rifkin A. In situ PCR for Mycobacterium tuberculosis in endoscopic mucosal biopsy specimens of intestinal tuberculosis and Crohn disease. American Journal of Clinical Pathology. 2008; 129:846851. https://doi.org/10.1309/DKKECWQWMG4J23E3.

34. Mokhtar DM, Abd-Elhafez EA, Hassan AHS. A Histological, Histochemical and Ultrastructural Study on the Fundic Region of the Stomach of Nile Catfish (Clarias gariepinus). Journal of Cytology \& Histology. 2015: 1-9. https://doi.org/10.4172/2157-7099.1000341. 